\title{
Sugar dynamics in large particles during in vitro incubation experiments
}

\author{
Christos Panagiotopoulos*, Richard Sempéré \\ Laboratoire de Microbiologie Géochimie et Ecologie Marine (LMGEM), CNRS/INSU, UMR 6117, Centre d'Océanologie de \\ Marseille, Université de la Méditerranée, Campus de Luminy, Case 901, 13288 Marseille Cedex 9, France
}

\begin{abstract}
Large particles (>60 $\mu \mathrm{m})$ were collected using in situ pumps deployed at 30 and $200 \mathrm{~m}$ depth at 2 typical stations in the southern Indian Ocean (Polar Front Zone [PFZ] and Sub-Antarctic Area [SAr]). The samples were incubated in vitro with their own bacterial assemblages for 7 to 17 days in batches under oxic conditions in the dark. Particulate organic carbon (POC) and sugars were monitored over time. Particulate sugars (PCHO-C) accounted for 5 to $20 \%$ of POC in the SAr, while they represented 5 to $8 \%$ of POC in the PFZ station at the beginning of the experiments. Molecular level analysis indicated that at the time of collection, ribose was among the most abundant sugars (18 to $30 \mathrm{wt} \%$ of PCHO-C) at the PFZ station and was rapidly degraded $\left(k=0.051\right.$ to $\left.0.058 \mathrm{~d}^{-1}\right)$ over the course of the experiment, while this sugar was below detection limits in the SAr. Our results also showed an increase in the relative abundance of deoxysugars (fucose and rhamnose), suggesting that these sugars have the potential to be used as indicators of the bacterial activity and evaluate the degradation status of POM in both areas. The kinetic study indicated that pentoses were degraded faster than hexoses, while deoxysugars exhibited the lowest degradation rates. This study demonstrated that total sugar degradation rates do not reflect the rates of all individual components, but rather a disparate collection of rates among sugars classes and individual sugars, which very likely can vary significantly in relation to the origin of particles.
\end{abstract}

KEY WORDS: Sinking particles · In vitro incubation experiments · Sugar degradation · Southern Indian Ocean

\section{INTRODUCTION}

Understanding the fate of particulate organic matter (POM) during microbial decomposition is important because marine aggregates represent the primary mode of particle flux to the ocean interior (Asper et al. 1992, Asper \& Smith 1999, Honjo et al. 2000), while most of marine primary production is recycled within the euphotic zone (Karl et al. 1988, Falkowski et al. 1998). During sedimentation, consumption of POM by bacteria produces degraded particulate organic carbon (POC) and dissolved organic carbon (DOC); the latter are further mineralized by free-living bacteria that release $\mathrm{CO}_{2}$ to the marine environment through respiration (Cho \& Azam 1988, Karner \& Herndl 1992, Smith et al. 1992, Hoppe et al. 1993, Sempéré et al.
2000). Earlier investigations indicated the importance of carbohydrates and proteins as bacterial substrates in POM and seawater (Smith et al. 1992, Keil \& Kirchman 1993, Skoog et al. 1999, Panagiotopoulos et al. 2002). Although the previous studies have provided some information on the fates of carbohydrate and protein, little quantitative molecular-level information is currently available on the alteration of carbohydrate in POM by marine bacteria. Furthermore, very few studies have provided data on the degradation rates of the total carbohydrate pool, carbohydrate classes (i.e. hexoses, pentoses) or individual monosaccharides.

Carbohydrates are generally considered as less labile compounds than amino acids and are, therefore, useful indicators to evaluate the degradation status of organic matter (Cowie \& Hedges 1984, 
Tanoue \& Handa 1987, Hedges et al. 1994, Hernes et al. 1996, Opshal \& Benner 1999, Panagiotopoulos \& Sempéré 2005a). For example, an increase in the weight percentage (wt\%) of deoxysugars associated with a decrease in wt\% of glucose is indicative of progressively degraded organic matter (Hedges et al. 1994). The latter observation was made while comparing different organic matter forms, including coarse $(>63 \mu \mathrm{m})$ and fine $(<63 \mu \mathrm{m})$ POM, and ultrafiltrated dissolved organic matter (UDOM). Similar patterns were also observed during decomposition of vascular plants (Opshal \& Benner 1999), polysaccharides excreted by phytoplanktonic species (Giroldo et al. 2003), and algal-derived DOM (Amon et al. 2001). Currently we do not know if these patterns are similar during decomposition of sinking POM because there is a dearth of molecular carbohydrate data of any kind in any marine environment. In a recent study based on sediment trapped material, Panagiotopoulos \& Sempéré (2005a) showed that a high relative abundance of glucose (30 to $35 \mathrm{wt} \%$ ) in sinking particles does not necessarily reflect the presence of fresh material.

Therefore, in order to obtain more information from the carbohydrate perspective on sinking particle dynamics during microbial degradation, large particles were collected using in situ pumps (ISP) and were further subjected to biodegradation experiments as previously described (Sempéré et al. 2000, Panagiotopoulos et al. 2002). This sequel study of our work on biodegradation experiments in the southern Indian Ocean (Panagiotopoulos et al. 2002) aims to: (1) contrast combined neutral sugar composition in sinking POM collected from different marine environments, notably the Polar Front Zone (PFZ) and the Sub-Antarctic Area (SAr), both located in the southern Indian Ocean; (2) examine whether wt\% of glucose and deoxysugars can be used as tracers of biological activities during decomposition; and (3) provide and compare degradation rates for individual sugar constituents during decomposition.

\section{MATERIALS AND METHODS}

Large particles $(>60 \mu \mathrm{m})$ were collected in January and February 1999 in the southern Indian Ocean at 2 stations: the Polar Front Zone (PFZ $\left.46^{\circ} \mathrm{S}, 62^{\circ} \mathrm{E}\right)$ and the Sub-Antarctic Area (SAr $\left.\sim 44^{\circ} \mathrm{S}, 63^{\circ} \mathrm{E}\right)$. General features of these sites are described in Panagiotopoulos et al. (2002). Detailed information about the study sites, including primary production, bacterial production, and total organic carbon (TOC) stocks, is presented in Table 1. Particles were collected at 30 and $200 \mathrm{~m}$ depth using ISP (Challenger Oceanics) equipped with $60 \mu \mathrm{m}$ pore-size filters (Nitex, $\varnothing: 142 \mathrm{~mm}$ ). These sampling depths (within and beneath the euphotic zone) were chosen to represent freshly produced and slightly degraded organic material, respectively.

Seawater (up to 10 l) was also collected at the same depths and filtered through $0.2 \mu \mathrm{m}$ pore-size filters (Millipore, $\varnothing: 142 \mathrm{~mm}$; pressure <50 mm Hg) in order to remove bacteria and grazers (Sempéré et al. 2000, Panagiotopoulos et al. 2002). This water was used to wash out particles from filters and for batch preparation. Extracted particles were likewise concentrated into a 21 polycarbonate bottle and immediately transferred to 4 to 5 incubation bottles ( $500 \mathrm{ml}$ each) using a peristaltic pump. Each bottle corresponds to the timepoint of the incubation (Table 2). This material was incubated at in situ seawater temperature $\left(5\right.$ to $\left.14^{\circ} \mathrm{C}\right)$ under oxic conditions and in the dark (Table 1). The headspace-to-sample ratio inside the incubation bottles was about 1:1, which ensured oxic conditions over the course of the incubation ( 7 to $17 \mathrm{~d}$; longer incuba-

Table 1. Summary of particle sampling conditions and in situ seawater characteristics. Large particles (>60 $\mu \mathrm{m})$ were collected using in situ pumps (ISP) deployed at 30 and $200 \mathrm{~m}$ at 2 stations in the southern Indian Ocean: Polar Front Zone (PFZ; $\sim 46^{\circ} 01.22^{\prime} \mathrm{S}, 62^{\circ} 56.70^{\prime} \mathrm{E}$ ) and Sub-Antarctic Area ( $\left.\mathrm{SAr} ; 4^{\circ} 10.92^{\prime} \mathrm{S}, 63^{\circ} 23.37^{\prime} \mathrm{E}\right)$. Euphotic zone depth was $150 \mathrm{~m}$ at both stations. Primary production (PP), bacterial production (BP), and total organic carbon (TOC) are integrated values to $1 \%$ of light penetration

\begin{tabular}{|c|c|c|c|c|c|c|}
\hline & $\begin{array}{l}\text { Sampling } \\
\text { depth (m) }\end{array}$ & $\begin{array}{l}\text { ISP filtered } \\
\text { volume (l) }\end{array}$ & $\begin{array}{c}\text { Seawater temp. } \\
\left({ }^{\circ} \mathrm{C}\right)\end{array}$ & $\begin{array}{l}\text { PP }\left(\mathrm{mmol}^{-2}\right. \\
\left.\mathrm{C} \mathrm{m}^{-2} \mathrm{~d}^{-1}\right)^{\mathrm{a}}\end{array}$ & BP $\underset{\left.\mathrm{d}^{-1}\right)^{\mathrm{b}, \mathrm{c}}}{\left(\mathrm{mmol} \mathrm{Cm}^{-2}\right.}$ & $\begin{array}{c}\text { TOC } \\
\left(\mathrm{mmol} \mathrm{C} \mathrm{m}^{-2}\right)^{\mathrm{b}}\end{array}$ \\
\hline PFZ & $\begin{array}{r}30 \\
200\end{array}$ & $\begin{array}{l}7471 \\
9906\end{array}$ & $\begin{array}{l}9 \\
5\end{array}$ & 28 & 8 & 7474 \\
\hline SAr & $\begin{array}{r}30 \\
200\end{array}$ & $\begin{array}{r}12068 \\
8013\end{array}$ & $\begin{array}{l}14 \\
12\end{array}$ & 47 & 13 & 9642 \\
\hline $\begin{array}{l}{ }^{\mathrm{a}} \mathrm{Leb} \\
{ }^{\mathrm{b}} \mathrm{R} . \mathrm{S} \\
{ }^{\mathrm{c}} \mathrm{Van}\end{array}$ & $\begin{array}{l}(2002) \\
\text { unpubl. dat } \\
\text { e (pers. cor }\end{array}$ & & & & & \\
\hline
\end{tabular}


Table 2. Elemental carbohydrate compositions (weight percent of particulate combined aldoses) and particulate combined aldose (PCHO-C) concentrations during biodegradation of $(>60 \mu \mathrm{m})$ particles collected with in situ pumps in the Polar Front Zone (PFZ) and Sub-Antarctic Area (SAr). The PCHO-C yields are the percentage of sugar-C to the POC pool (PCHO-C/POC). Fuc: fucose, Rha: rhamnose, Ara: arabinose, GlcN: glucosamine, Gal: galactose, Glc: glucose, Man: mannose, Xyl: xylose, Fru: fructose, Rib: ribose

\begin{tabular}{|c|c|c|c|c|c|c|c|c|c|c|c|c|c|}
\hline $\begin{array}{l}\text { Sampling } \\
\text { depth (m) }\end{array}$ & $\begin{array}{l}\text { Incubation } \\
\text { period (d) }\end{array}$ & Fuc & Rha & Ara & GlcN & Gal & Glc & Man & Xyl & Fru & Rib & $\begin{array}{c}\mathrm{PCHO}-\mathrm{C} \\
\left(\mathrm{mg} \mathrm{l}^{-1}\right)\end{array}$ & $\begin{array}{c}\mathrm{PCHO}-\mathrm{C} / \mathrm{POC} \\
(\%)\end{array}$ \\
\hline \multicolumn{14}{|l|}{ PFZ } \\
\hline \multirow[t]{6}{*}{30} & 0 & 3.59 & 2.05 & 2.38 & 0.98 & 19.9 & 22.6 & 5.38 & 8.78 & 4.92 & 29.5 & 0.49 & 4.64 \\
\hline & 1 & 3.67 & 2.38 & 2.24 & 1.75 & 18.1 & 19.0 & 5.92 & 8.40 & 3.95 & 34.6 & 0.38 & 5.61 \\
\hline & 2 & 3.36 & 3.18 & 0.87 & 2.27 & 16.9 & 22.0 & 6.07 & 6.85 & 4.84 & 33.6 & 0.40 & 4.55 \\
\hline & 4 & 3.48 & 3.82 & 1.09 & 3.82 & 17.1 & 16.0 & 3.95 & 7.59 & 4.98 & 38.2 & 0.30 & 3.40 \\
\hline & 7 & 5.63 & 3.97 & 2.30 & 3.15 & 21.0 & 24.5 & 5.62 & 8.76 & 5.30 & 19.7 & 0.40 & 4.96 \\
\hline & 13 & 5.34 & 6.67 & 0.57 & 2.10 & 22.0 & 24.2 & 6.05 & 10.7 & 7.66 & 14.7 & 0.39 & 6.61 \\
\hline \multirow[t]{5}{*}{200} & 0 & 3.04 & 1.26 & - & 10.5 & 16.2 & 31.9 & 7.17 & 7.72 & 4.11 & 18.1 & 0.33 & 7.62 \\
\hline & 1 & 3.58 & 1.66 & - & 8.47 & 19.8 & 28.3 & 6.30 & 13.1 & 8.86 & 9.98 & 0.31 & 8.89 \\
\hline & 4 & 4.74 & 2.85 & - & 14.8 & 19.4 & 23.0 & 8.47 & 8.77 & 5.13 & 12.8 & 0.36 & 9.01 \\
\hline & 9 & 7.10 & 5.69 & - & 12.1 & 24.6 & 34.3 & 6.86 & 9.34 & - & - & 0.25 & 6.32 \\
\hline & 17 & 10.0 & 5.80 & - & 9.08 & 24.2 & 26.6 & 9.95 & 14.4 & - & - & 0.23 & 7.72 \\
\hline \multicolumn{14}{|l|}{ SAr } \\
\hline \multirow[t]{6}{*}{30} & 0 & 4.27 & 3.52 & 1.02 & 0.83 & 21.6 & 54.5 & 5.64 & 8.62 & - & - & 1.10 & 19.9 \\
\hline & 1 & 3.98 & 3.40 & 1.09 & 1.68 & 21.7 & 51.0 & 7.11 & 10.1 & - & - & 1.39 & 23.8 \\
\hline & 2 & 4.76 & 3.49 & 1.12 & 1.43 & 23.9 & 48.8 & 6.56 & 9.97 & - & - & 0.81 & 16.4 \\
\hline & 4 & 5.23 & 4.58 & 1.33 & 2.55 & 26.6 & 39.4 & 8.20 & 12.1 & - & - & 1.05 & 20.1 \\
\hline & 7 & 5.74 & 5.88 & 1.01 & 2.03 & 25.7 & 42.6 & 6.80 & 10.3 & - & - & 0.62 & 13.8 \\
\hline & 14 & 8.17 & 7.25 & 0.46 & 0.69 & 26.2 & 37.4 & 7.32 & 12.6 & - & - & 0.50 & 12.0 \\
\hline \multirow[t]{5}{*}{200} & 0 & 4.25 & 3.44 & 1.56 & 0.99 & 12.9 & 57.4 & 6.62 & 12.9 & - & - & 0.101 & 5.08 \\
\hline & 1 & 5.07 & 1.96 & 0.88 & 2.36 & 13.3 & 56.6 & 6.56 & 13.2 & - & - & 0.079 & 5.88 \\
\hline & 2 & 4.04 & 3.16 & 1.53 & 2.78 & 12.8 & 60.5 & 4.48 & 10.8 & - & - & 0.098 & 8.61 \\
\hline & 4 & 3.12 & 2.66 & 1.48 & 2.50 & 9.75 & 69.4 & 4.00 & 7.13 & - & - & 0.117 & 9.10 \\
\hline & 7 & 5.76 & 4.37 & 2.52 & 2.16 & 14.7 & 55.9 & 4.05 & 10.5 & - & - & 0.065 & 4.19 \\
\hline
\end{tabular}

tion times would probably induce anoxic conditions). Incubation bottles were also gently and regularly swirled upside down to homogenize their contents and avoid particle deposition on the walls.

Biodegradation experiments were only conducted once at each depth due to a limited amount of particulate material. Sub-sampling of incubations was performed regularly by collecting aliquots for POC and particulate sugars (PCHO-C) in precombusted glass bottles $\left(450^{\circ} \mathrm{C}, 6 \mathrm{~h}\right)$. Particles were collected on $\mathrm{GF} / \mathrm{F}$ filters (nominative retention, $0.7 \mu \mathrm{m}$ ) and stored in the dark at $-17^{\circ} \mathrm{C}$. Incubation sub-samples were analyzed using previously described methods for POC (Tan \& Strain 1979) and neutral sugars (Panagiotopoulos et al. 2001, Panagiotopoulos \& Sempéré 2005a,b). At the beginning of the incubation, the standard deviation for particle distribution was $5 \%$ (POC measurements in 5 replicates). During the course of the incubations experimental errors, based on duplicate analysis of sub-samples, were estimated to be about $10 \%$ for the concentration of each chemical variable (POC and PCHO). A 2-fold replicate analysis of individual monosaccharides had a standard deviation of $<8 \%$ for all sugars except ribose $(15 \%)$.
Particulate sugar degradation rates. Particulate sugar degradation rates $(k)$ were calculated according to the formula (Amon \& Benner 1996):

$$
k=\left(C_{\text {init }} \times C_{\text {fin }}\right) \times(t)^{-1} \times\left(C_{\text {init }}\right)^{-1}
$$

where $C_{\text {init }}$ and $C_{\text {fin }}$ are the initial and final concentration $\left(\mu \mathrm{g} \mathrm{l}^{-1}\right)$ of any constituent, respectively, and $t$ is the incubation time (days). To analyze the relative proportion of the particulate fraction of each individual sugar that is available for bacterial consumption, all rates were normalized to the initial concentration of the incubation (Panagiotopoulos et al. 2002).

\section{RESULTS}

\section{In situ PCHO-C concentrations}

In situ PCHO-C concentrations in large (>60 $\mu \mathrm{m})$ particles from $30 \mathrm{~m}$ depth at both PFZ and SAr stations

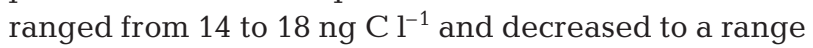

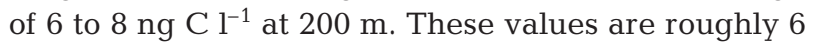
orders of magnitude lower than those measured at the beginning of the biodegradation experiment (Table 2). 
Table 3. Degradation rates $(k)$ of particulate combined aldoses (PCHO-C), hexoses, pentoses, deoxysugars, and individual mono-

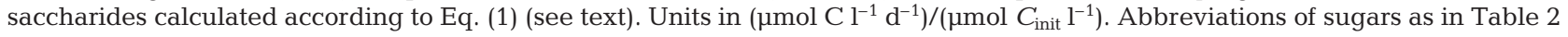

\begin{tabular}{|c|c|c|c|c|c|c|c|c|c|c|c|c|c|c|}
\hline $\begin{array}{l}\text { Sampling } \\
\text { depth (m) }\end{array}$ & $k_{\mathrm{PCHO}-\mathrm{C}}$ & $k_{\text {hexoses }}$ & $k_{\text {pentoses }}$ & $k_{\text {deoxysugars }}$ & $k_{\text {Fuc }}$ & $k_{\mathrm{Rha}}$ & $k_{\text {Ara }}$ & $k_{\mathrm{GlcN}}$ & $k_{\mathrm{Gal}}$ & $k_{\mathrm{Glc}}$ & $k_{\mathrm{Man}}$ & $k_{\mathrm{XYl}}$ & $k_{\text {Fru }}$ & $k_{\text {Rib }}$ \\
\hline \multicolumn{15}{|l|}{ PFZ } \\
\hline 30 & 0.016 & 0.021 & 0.044 & -0.032 & 0.001 & -0.090 & 0.065 & 0.023 & 0.020 & 0.022 & 0.019 & 0.015 & 0.018 & 0.051 \\
\hline 200 & 0.018 & 0.016 & 0.037 & -0.084 & -0.070 & -0.120 & - & 0.025 & 0.001 & 0.026 & 0.005 & 0.025 & 0.057 & 0.058 \\
\hline \multicolumn{15}{|l|}{ SAr } \\
\hline 30 & 0.038 & 0.041 & 0.024 & 0.008 & 0.004 & 0.014 & 0.055 & 0.042 & 0.029 & 0.047 & 0.026 & 0.020 & - & - \\
\hline 200 & 0.049 & 0.047 & 0.054 & 0.013 & 0.009 & 0.018 & 0.001 & 0.028 & 0.030 & 0.047 & 0.083 & 0.063 & - & - \\
\hline
\end{tabular}

Assuming a sinking velocity of $100 \mathrm{~m} \mathrm{~d}^{-1}$ (Alldredge \& Silver 1988), these in situ $\mathrm{PCHO}-\mathrm{C}$ concentrations correspond to a theoretical sugar flux at $200 \mathrm{~m}$ of $0.83 \mathrm{mg}$ $\mathrm{C} \mathrm{m}^{-2} \mathrm{~d}^{-1}$ for SAr and $0.64 \mathrm{mg} \mathrm{C} \mathrm{m}^{-2} \mathrm{~d}^{-1}$ for PFZ, which is in the same order of magnitude as the fluxes estimated from the sediment traps (Panagiotopoulos \& Sempéré 2005a).

\section{Concentrations, relative abundances, and degradation rates of $\mathrm{PCHO}-\mathrm{C}$}

In the PFZ biodegradation experiments, PCHO-C concentrations decreased by 20 and $30 \%$ from their initial concentration at 30 and $200 \mathrm{~m}$, respectively, while the corresponding decreases at SAr were 54 and $36 \%$ at 30 and $200 \mathrm{~m}$ (Table 2). The PCHO-C yields (defined as PCHO-C/POC ratios) increased slightly for PFZ particles from 5 to $7 \%$ at $30 \mathrm{~m}$ and remained constant $(\sim 8 \%)$ at $200 \mathrm{~m}$ over the course of the experiment (Table 2). In contrast, in the SAr experiment, PCHO-C yields at 30 and $200 \mathrm{~m}$ depths decreased from 20 to $12 \%$ and from 5 to $4 \%$, respectively, over the course of the experiment.

The initial sugar composition at SAr varied only slightly between the 2 depths, with the exception of galactose (Table 2). At SAr, the collected particulate material was characterized by the dominance of glucose (55 and $57 \mathrm{wt} \%$ at 30 and $200 \mathrm{~m}$ depth, respectively) followed by galactose (22 and $13 \mathrm{wt} \%$ at 30 and $200 \mathrm{~m}$ ) and xylose (9 and $13 \mathrm{wt} \%$ at 30 and $200 \mathrm{~m}$ ). The remaining sugars contributed $<7 \mathrm{wt} \%$ to the carbohydrate pool. It is important to note that ribose and fructose were below detection limits, indicating the absence of storage or intracellular polysaccharides in SAr particles at $t=0$. In contrast, PFZ particles at $30 \mathrm{~m}$ at $t=0$ were characterized by the dominance of ribose (30 wt \%) followed by glucose (23 wt\%), galactose (20 wt \%), and xylose (9 wt\%). For PFZ particles at 200 $\mathrm{m}$, glucose was initially the major aldose ( 32 wt \%), followed by ribose (18 wt\%), galactose (16 wt \%), and xylose (8 wt\%) (Table 2).
In all experiments for both stations, major decreases in the concentration ( $\mu \mathrm{g} \mathrm{C}^{-1}$ ) of pentoses (arabinose, xylose, and ribose) and hexoses (mannose, glucose, and galactose) were observed. Conversely, the concentrations of deoxysugars (fucose and rhamnose) increased at PFZ and remained stable at SAr. The relative abundances of mannose, arabinose, xylose, fucose, and rhamnose increased or remained constant, while those of glucose and ribose always decreased over time at both stations, suggesting a selective extraction of these sugars from POM.

Calculated values of $k$ for PFZ and SAr stations at both depths were 0.016 to $0.049 \mathrm{~d}^{-1}$ for PCHO-C and 0.001 to $0.083 \mathrm{~d}^{-1}$ for individual monosaccharides. At the PFZ station, negative degradation values were recorded for deoxysugars due to the fact that concentrations of these sugars (sum of fucose and rhamnose) increased over time (Table 3). This result was surprising since Amon et al. (2001) found that fucose and rhamnose generally remained constant (or increased slightly) during a short incubation period. Therefore, for the remainder of this investigation the negative degradation values for rhamnose, fucose, and deoxysugars at PFZ (30 and $200 \mathrm{~m}$ ) were excluded.

\section{DISCUSSION}

\section{PCHO-C yields and relative abundance of combined aldoses in ISP}

At the beginning of the biodegradation experiments, particulate combined aldoses comprised $<8 \%$ of the POC pool (except SAr particles at $30 \mathrm{~m}$; Table 2). These results are in agreement with earlier investigations carried out in sediment traps at other locations including the central equatorial Pacific Ocean (5 to 18\%, Hernes et al. 1996), North Pacific ( 7 to $10 \%$, Tanoue \& Handa 1987), Sargasso Sea (3 to 6\%, Ittekkot et al. 1984), southern Indian Ocean (3 to $4 \%$, Panagiotopoulos \& Sempéré 2005a), and Mediterranean Sea (4 to 16\%, Kerhervé et al. 1999, 
Panagiotopoulos \& Sempéré 2005a). It is important to note that at $t=0$, amino acids were predominant in PFZ particles, accounting for $\sim 38 \%$ of POC, while they represented only $\sim 15 \%$ of POC in SAr particles (Panagiotopoulos et al. 2002). Since amino acids are indicative of fresh algal detritus and are more rapidly degraded than other biochemical classes (Harvey et al. 1995, Harvey \& Mannino 2001), their high relative abundance at PFZ suggests that particles initially collected were less degraded than in SAr waters. Therefore, the low initial PCHO-C yields measured at PFZ $(5 \%)$ compared with those at SAr $(20 \%)$ imply the presence of fresh material at the PFZ station (Table 2).

Our results also showed that at $t=0$ ribose was the major aldose at PFZ at $30 \mathrm{~m}$, but was second in abundance at PFZ at $200 \mathrm{~m}$. These results are comparable with those reported in sinking particles in the same area using sediment traps (Panagiotopoulos \& Sempéré 2005a). The difference in the relative abundance of sugars collected in sediment traps (Panagiotopoulos \& Sempéré 2005a) and ISP (present study) may be due to the fact that ISP collect a wide spectrum of particles sizes (small and large), while sediment traps collect only fast sinking particles. It is also likely that small particles absorbed in the in situ pump filters are more degraded than large sinking particles collected with sediment traps. However, the high abundance of ribose in PFZ particles at $t=0$ indicates the presence of non-structural and labile compounds, which might be further degraded rapidly by bacteria (Table 2). This result corroborates our previous observations suggesting that sinking particles in PFZ waters were less degraded than those in SAr waters. Finally, glucose was the major aldose (>32 wt\%) at SAr station followed by galactose and xylose (Table 2). Similar results have also been reported for sediment trap samples in other oceanic areas (Tanoue \& Handa 1987, Hernes et al. 1996, Panagiotopoulos \& Sempéré 2005a).

\section{PCHO-C dynamics during bacterial degradation}

With the exception of PFZ particles at $200 \mathrm{~m}$, in which we observed an accumulation of sugars in the total dissolved fraction, dissolved sugar (DCHO-C) concentrations closely followed the decrease of PCHOC, implying a rapid bacterial assimilation of dissolved monosaccharides or oligosaccharides produced during POC decomposition. We did not analyze sugars in the dissolved fraction by chromatography, only the total amount of dissolved sugars is measured by colorimetric techniques (see Panagiotopoulos et al. 2002). Nevertheless, our results indicated comparable de-

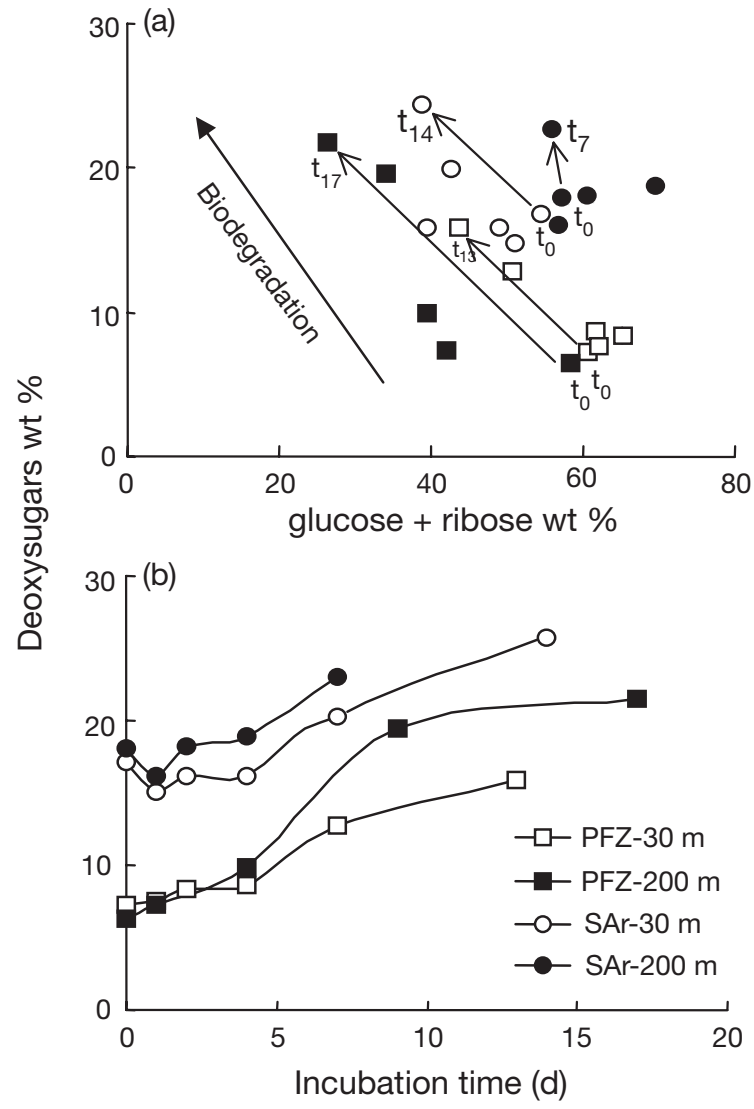

Fig. 1. (a) Plot of weight percentage (wt\%) of deoxysugars (fucose plus rhamnose) vs. wt $\%$ of glucose plus ribose and (b) wt \% of deoxysugars during biodegradation experiments. Weight percentages of deoxysugars and ribose were calculated on a glucose-free basis

creases in both fractions (PFZ at $30 \mathrm{~m}, 21 \%$ for PCHO$\mathrm{C}$ and $17 \%$ for DCHO-C; $\mathrm{SAr}$ at $30 \mathrm{~m}, 54 \%$ for PCHO$\mathrm{C}$ and $43 \%$ for DCHO-C; SAr at $200 \mathrm{~m}, 34 \%$ for PCHO-C and $37 \%$ for DCHO-C), indicating that $\mathrm{PCHO}-\mathrm{C}$ concentrations in batches are likely to better represent the decay of sugars in POM.

The 2 most striking changes in composition of neutral sugars during biodegradation were the rapid decrease in the wt\% of glucose and ribose, and the increase in wt $\%$ of deoxysugars (fucose and rhamnose; Fig. 1a). Glucose is considered to be a labile compound of storage polysaccharides ( $\beta$ 1-3 glucanes), while ribose is a common component of RNA and nucleotides (Haug \& Myklestad 1976, Cowie \& Hedges 1984, Hicks et al. 1994). The high decrease of glucose and ribose and the relative increase of mannose, xylose, and galactose over time clearly suggests a selective extraction of these labile sugars (glucose and ribose) from the $\mathrm{PCHO}-\mathrm{C}$ pool and is in agreement with previous investigations (Tanoue \& Handa 1987, Hernes et al. 1996). 

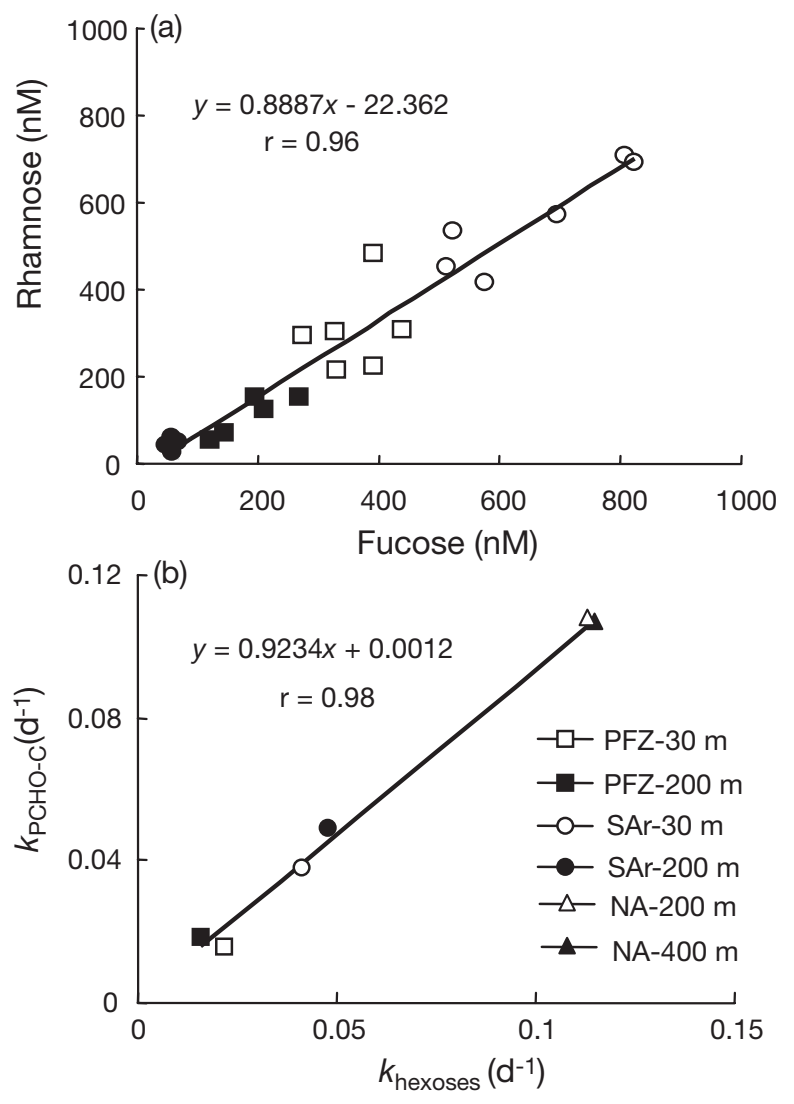

Fig. 2. (a) Correlation between fucose and rhamnose at 30 and $200 \mathrm{~m}$ depth, for the Polar Front Zone (PFZ) and SubAntarctic (SAr) stations during biodegradation experiments. (b) Correlation between degradation rates $(k)$ of PCHO-C and hexoses. We included some of our unpublished data from other biodegradation experiments in the north Atlantic Ocean (NA at 200 and $400 \mathrm{~m}$ depth) performed in the same way as the present experiments

The relative increase of deoxysugars during decomposition has already been reported for several organic matter types and environments (Cowie \& Hedges 1984, Hedges et al. 1994, Opsahl \& Benner 1999, Amon et al. 2001, Giroldo et al. 2003) and is often attributed to the high abundance of fucose and rhamnose in bacteria (Ogier et al. 2001). Our results indicated that particles at the PFZ station were initially rich in amino acids (Panagiotopoulos et al. 2002) and ribose, and relatively poor in deoxysugars (6.3 to $7.3 \mathrm{wt} \%$ ), while the opposite observation was found at SAr (17.1 to $18.0 \mathrm{wt} \%$ deoxysugars; Fig. 1b). This result reinforces the idea that elevated relative abundance of deoxysugars is found in highly degraded material. As Fig. 2b indicates, after 13 to $17 \mathrm{~d}$ of decomposition deoxysugars wt $\%$ values in PFZ particles reached those of SAr particles (SAr at $t=0$ ), which also suggests a difference in degradation status between PFZ and SAr particles. These results illustrate that deoxysugars have the potential to be used as indicators of the bacterial activity and to evaluate the degradation status of POM. The high abundance of fucose and rhamnose in bacteria, and therefore in POM during decomposition, is further confirmed by a highly significant correlation ( $\mathrm{r}=0.96$; $\mathrm{p}<0.01 ; \mathrm{n}=22$ ) between these deoxysugars in the collected particles (Fig. 2a).

\section{Kinetics of PCHO-C and individual monosaccharides during bacterial degradation}

Although the literature contains a plethora of values on degradation rates of bulk organic matter, including sinking particles, sediments, and phytoplankton, few studies provide data on $\mathrm{PCHO}-\mathrm{C}$ degradation rates (Westrich \& Berner 1984, Harvey et al. 1995, Rabouille et al. 2000, Sempéré et al. 2000, Panagiotopoulos et al. 2002). Furthermore, little data exist for the degradation rates of sugar classes and individual monosaccharides. In this study, degradation rates of $\mathrm{PCHO}-\mathrm{C}$ ranged from 0.016 to $0.049 \mathrm{~d}^{-1}$, resulting in a residence time of 20 to $63 \mathrm{~d}$. Using a $1 \mathrm{G}$ model in a flow-through system during phytoplankton decay Harvey et al. (1995) reported degradation rates of $\mathrm{PCHO}-\mathrm{C}$ ranging from 0.092 to $0.094 \mathrm{~d}^{-1}$ for an incubation period of 45 to $77 \mathrm{~d}$. However, if these rates were calculated according to Eq. (1) they would range from 0.013 to $0.021 \mathrm{~d}^{-1}$, which is in the same order of magnitude as the present study. Similarly, Giroldo et al. (2003) applied a 1G model during microbial degradation of extracellular polysaccharide and observed sugar degradation rates in the order of $0.050 \mathrm{~d}^{-1}$ for an incubation period of $35 \mathrm{~d}$. However, if their results were calculated in the same manner as our study they would correspond to a degradation rate of $0.025 \mathrm{~d}^{-1}$, again in agreement with this study.

Therefore, during decomposition of fresh organic matter (sinking particles, phytoplankton, extracellular polysaccharides) particulate sugars have a residence time of 20 to $77 \mathrm{~d}$, or roughly 1 to $3 \mathrm{mo}$, indicating that these compounds are major components of semilabile DOC. It is worth noting that these residence time values were always higher than those of amino acids, but comparable with or lower than lipids, which is consistent with the initial chemical composition reported for phytoplankton and fast-sinking particles (20 to $60 \%$ amino acids, 10 to $15 \%$ lipids, and 2 to $15 \%$ sugars; Harvey et al. 1995, Wakeham et al. 1997, Panagiotopoulos et al. 2002, Panagiotopoulos \& Sempéré 2005a). This further suggests that the mechanisms that control particle degradation also depend on their initial chemical composition (Wakeham et al. 1997, Panagiotopoulos et al. 2002).

Degradation rates of sugar classes (hexoses, pentoses, and deoxysugars) ranged from 0.008 to $0.054 \mathrm{~d}^{-1}$, 
resulting in a residence time of 19 to $125 \mathrm{~d}$. The highest residence time corresponded with deoxysugar degradation (SAr at 30 and $200 \mathrm{~m}$ ), while the lowest time with that of hexoses (mannose and glucose) and some pentoses (ribose). As previously indicated little current data exist for sugar classes and individual monosaccharides degradation rates in the literature. Therefore, the present data cannot be compared with values existing for sugar degradation rates. However, we can note from literature that degradation rates of some lipid classes (free fatty acids, sterols and triacylglycerols) during fresh algal decomposition fall in the range of 0.026 to $0.092 \mathrm{~d}^{-1}$ (Harvey \& Macko 1997, Caradec et al. 2004). Again if these values were calculated according to Eq. (1) they would range from 0.011 to $0.022 \mathrm{~d}^{-1}$, which is in agreement with the present study (Table 3).

Pentoses also degraded faster than hexoses, and deoxysugars exhibited the slowest degradation rates (Table 3). This result was somewhat surprising, since we observed a strong correlation $(\mathrm{r}=0.98 ; \mathrm{p}<0.01$; $\mathrm{n}=$ 6 ) between degradation rates of $\mathrm{PCHO}-\mathrm{C}$ and hexoses. This indicates that sugar degradation rates are controlled mainly by the degradation of hexoses, which are generally more abundant than pentoses in sinking particles (Hernes et al. 1996, Panagiotopoulos \& Sempéré 2005a). A weaker correlation $(\mathrm{r}=0.88 ; \mathrm{p}=0.01$; $\mathrm{n}=6$ ) was observed between $\mathrm{PCHO}-\mathrm{C}$ and pentoses degradation rates. Therefore, it seems likely that degradation rates of very labile compounds such as ribose, which in some cases may be dominant sugars in POM (e.g. PFZ particles at $30 \mathrm{~m}$ ), are not directly reflected in the total carbohydrate pool degradation rate.

Individual sugar degradation rates were higher at the SAr station than at the PFZ, which corroborates the bulk degradation PCHO-C rates (Table 3 ). This further suggests that sugars were more efficiently degraded in SAr than in PFZ sinking particles, in agreement with their initial higher relative abundance at SAr. With the exception of SAr particles at $200 \mathrm{~m}$, glucose degradation rates were always higher than those of galactose and mannose. Galactose and mannose are derived from structural polysaccharides (i.e galactans, mannans, galactomannans), while glucose comes from both structural and storage compounds of marine phytoplankton (Hecky et al. 1973, Haug \& Myklestad 1976, Tanoue \& Handa 1987). The higher degradation rates of glucose compared with mannose and galactose clearly suggest the preferential use of glucose storage compounds and is in agreement with previous investigations (Hernes et al. 1996, Panagiotopoulos \& Sempéré 2005a).

The present data clearly demonstrate that total sugar degradation rates do not reflect the rates of all individ- ual components but rather a disparate collection of rates among sugars classes and individual sugars, which can vary significantly. Additional studies are needed to examine the bacterial degradation of POM, specifically to focus on other sugar classes or individual compounds such as amino sugars and uronic acids.

Acknowledgements. We thank the captain and crew of the RV 'Marion Dufresne' for excellent service at sea as well as J. Le Fèvre (leader of the Antares project) and M. Denis (chief scientist of Antares-4 oceanographic cruise). We thank C. Jeandel, C. Bournot-Marec, and L. Coppola for assistance in sample collection and batch preparation. We also thank R. Lafont, L. Ziolkowski, and the 2 anonymous reviewers for valuable comments and suggestions. This research was supported by France-PROOF Antares-4 project. Financial support for C.P. came from the Alexander S. Onassis Public Benefit Foundation, Greece.

\section{LITERATURE CITED}

Alldredge AL, Silver MW (1988) Characteristics, dynamics and significance of marine snow. Prog Oceanogr 20:41-82

Amon RMW, Benner R (1996) Bacterial utilization of different classes of dissolved organic matter. Limnol Oceanogr 41: 41-51

Amon RMW, Fitznar HP, Benner R (2001) Linkages among the bioreactivity, chemical composition, and diagenetic state of marine dissolved organic matter. Limnol Oceanogr 46: $287-297$

Asper VL, Smith WO Jr (1999) Particle fluxes during austral spring and summer in the southern Ross Sea (Antarctica). J Geophys Res 104:5345-5360

Asper VL, Deuser WG, Knauer GA, Lohrenz SE (1992) Rapid coupling of sinking particle fluxes between surface and deep ocean waters. Nature 357:670-672

Caradec S, Grossi V, Gilbert F, Guigue C, Goutx M (2004) Influence of various redox conditions on the degradation of microalgal triacylglycerols and fatty acids in marine sediments. Org Geochem 35:277-287

Cho BC, Azam F (1988) Major role of bacteria in biogeochemical fluxes in the ocean's interior. Nature 332:441-443

Cowie GL, Hedges JI (1984) Carbohydrate sources in a coastal marine environment. Geochim Cosmochim Acta 48:2075-2087

Cowie GL, Hedges JI (1994) Biochemical indicators of diagenic alteration in natural organic matter mixtures. Nature 369:304-307

Falkowski PG, Barber RT, Smetacek V (1998) Biogeochemical controls and feedbacks on ocean primary production. Science 281:200-206

Giroldo D, Vieira AAH, Paulsen BS (2003) Relative increase of deoxysugars during microbial degradation of an extracellular polysaccharide released by a tropical freshwater Thalassiosira sp. (Bacillarophyceae). J Phycol 39: $1109-1115$

Harvey HR, Macko SA (1997) Kinetics of phytoplankton decay during simulated sedimentation: changes in lipids under oxic and anoxic conditions. Org Geochem 27: $129-140$

Harvey HR, Mannino A (2001) The chemical composition and cycling of particulate and macromolecular dissolved organic matter in temperate estuaries as revealed by molecular organic tracers. Org Geochem 32:527-542 
Harvey HR, Tuttle JH, Bell JT (1995) Kinetics of phytoplankton decay during simulated sedimentation: changes in biochemical composition and microbial activity under oxic and anoxic conditions. Geochim Cosmochim Acta 59: $3637-3377$

Haug A, Myklestad SV (1976) Polysaccharides of marine diatoms with special reference to Chaetocheros species. Mar Biol 34:217-222

Hecky RE, Mopper K, Kilham P, Degens ET (1973) The amino acid and sugar composition of diatom cell-walls. Mar Biol 19:323-331

Hedges JI, Cowie GL, Richey JE, Quay PD, Benner R, Strom M, Forsberg BR (1994) Origins and processing of organic matter in the Amazon River as indicated by carbohydrates and amino acids. Limnol Oceanogr 39:743-761

Hernes PJ, Hedges JI, Peterson ML, Wakeham SG, Lee C (1996) Neutral carbohydrate geochemistry of particulate material in the central equatorial Pacific. Deep-Sea Res II 43:1181-1204

Hicks RA, Owen CJ, Aas P (1994) Deposition, resuspension, and decomposition of particulate organic matter in sediments of Lake Itasca, Minnesota, USA. Hydrobiologia 284: 79-91

Honjo S, Francois R, Manganini S, Dymond J, Collier R (2000) Particle fluxes to the interior of the Southern Ocean in the Western Pacific sector along $170^{\circ} \mathrm{W}$. Deep-Sea Res 47 : 3521-3548

Hoppe HG, Ducklow H, Karrash B (1993) Evidence for dependency of bacterial growth on enzymatic hydrolysis of particulate organic matter in the mesopelagic ocean. Mar Ecol Prog Ser 93:277-283

Ittekkot V, Deuser WG, Degens ET (1984) Seasonality in the fluxes of sugars, amino acids, and amino sugars to the deep ocean: Sargasso Sea. Deep-Sea Res 31:1057-1069

Karl DM, Knauer GA, Martin JH (1988) Downward flux of particulate organic matter in the ocean. A particle decomposition paradox. Nature 332:438-441

Karner M, Herndl GJ (1992) Extracellular enzymatic activity and secondary production in free-living and marinesnow-associated bacteria. Mar Biol 113:341-347

Keil RG, Kirchman DL (1993) Dissolved amino acids: chemical form and utilization by marine bacteria. Limnol Oceanogr 38:1256-1270

Kerhervé $\mathrm{P}$, Heussner $\mathrm{S}$, Charrière $\mathrm{B}$, Stavrakakis $\mathrm{S}$, Ferrand JL, Monaco A, Delsaut N (1999) Biogeochemistry and dynamics of settling particle fluxes at the Antikythira Strait (Eastern Mediterranean). Prog Oceanogr 44: 651-675

Ogier S, Disnar JR, Albéric P, Bourdier G (2001) Neutral car-

Editorial responsibility: Otto Kinne (Editor-in-Chief),

Oldendorf/Luhe, Germany bohydrate geochemistry of particulate material (trap and core sediment) in a eutrophic lake (Aydat France). Org Geochem 32:151-162

Opsahl S, Benner R (1999) Characterization of carbohydrates during early diagenesis of five vascular plant tissues. Org Geochem 30:83-94

Panagiotopoulos C, Sempéré R (2005a) The molecular distribution of combined aldoses in sinking particles in various oceanic conditions. Mar Chem 95:31-49

Panagiotopoulos C, Sempéré R (2005b) Analytical methods for the determination of sugars in aquatic environments: a historical perspective and future directions. Limnol Oceanogr Methods 3:419-454

Panagiotopoulos C, Sempéré R, Lafont R, Kerhervé P (2001) Sub-ambient temperature effects on separation of monosaccharides by HPAEC-PAD. Application to marine chemistry. J Chromatogr A 920:13-22

Panagiotopoulos C, Sempéré R, Obernosterer I, Striby L, Goutx M, Van Wambeke F, Gautier S, Lafont R (2002) Bacterial degradation of large particles in the southern Indian Ocean using in vitro incubation experiments. Org Geochem 33:985-1000

Rabouille C, Gaillard JF, Relexans JC, Treguer P, Vincendeau MA (1998) Recycling of organic matter in Antarctic sediments: a transect through the polar front in the southern Ocean (Indian Sector). Limnol Oceanogr 43:420-432

Sempéré R, Yoro SC, Van Wambeke F, Charrière B (2000) Microbial decomposition of large organic particles in the Northwestern Mediterranean Sea: an experimental approach. Mar Ecol Prog Ser 198:61-72

Skoog A, Biddanda B, Benner R (1999) Bacterial utilization of dissolved glucose in the upper water column of the Gulf of Mexico. Limnol Oceanogr 44:1625-1633

Smith DC, Simon M, Alldredge A, Azam F (1992) Intense hydrolytic enzyme activity on marine aggregates and implications for rapid particles dissolution. Nature 359: 139-142

Tan FC, Strain PM (1979) Carbon isotope ratios of particulate organic matter in the Gulf of St. Lawrence. J Fish Res Board Can 36:678-682

Tanoue E, Handa N (1987) Monosaccharide composition of marine particles and sediments from the Bering Sea and northern North Pacific. Oceanol Acta 10:91-99

Wakeham SG, Lee C, Hedges JI, Hernes PJ, Peterson ML (1997) Molecular indicators of diagenetic status in marine organic matter. Geochim Cosmochim Acta 61:5363-5369

Westrich J, Berner R (1984) The role of sedimentary organic matter in bacterial sulphate reduction: the G model tested. Limnol Oceanogr 29:236-249

Submitted: October 25, 2005; Accepted: June 21, 2006

Proofs received from author(s): January 10, 2007 